\title{
Solar Electricity Over Three Continents
}

\author{
Kamel HAINE ${ }^{1 *}$, Dagnija BLUMBERGA ${ }^{2}$ \\ ${ }^{1,2}$ Riga Technical University, Institute of Energy Systems and Environment, Äzenes iela 12/1, \\ Riga, LV-1048, Latvia
}

\begin{abstract}
Modern urban planning in the world is nowadays facing severe problems due to the fast increase of the population and migration from villages to cities, which led countries to implementation of strategy of fast, modern urban planning to meet the needs of the population. Since the $1980 \mathrm{~s}$, in a context marked by increasing development in energy costs and by rising attention to the problem of global warming, countries have gradually mobilized to control their energy better and reduce the environmental footprint. However, even if there are some great successes, the deployment of renewable energies is still not well developed in developing countries such as Algeria that mainly uses fossil fuels. Considering the huge potential and good climatic conditions, developing countries should take on renewable energies for their future development. This paper aims to understand the impact of modern urban strategy on the application of solar urban planning. This study will clarify the critical role of solar electricity integration used in determining the urban solar potential in four studied regions located on three different continents: Africa, Europe and North America, in the cities of Ibenbadis (Constantine, Algeria), Saint-Hugues (Quebec, Canada), Saint-Malo (France) and Ambolobozobe (Madagascar). The results obtained will allow a comparison of the calculated solar energy potential of three urban sites, the benefits of reducing carbon dioxide as well as a comparison of solar energy costs on three continents.
\end{abstract}

Keywords - PV integration solar electricity; solar potential; topological analysis; urban network; urban forms

\section{INTRODUCTION}

Rapid urban development, which favours a lower density of buildings in peri-urban areas than in the city centre results in unorganized urbanization. This practice is a significant generator of greenhouse gases (GHG) and atmospheric pollutant emissions, particularly in the building sector. The sustainability of the urban environment has a significant impact on the decarbonisation process. Many authors [1]-[4] stress the importance of energy-efficient urban planning in modern urbanism. Whilst developed countries successfully adopted green urban planning; in developing countries, adopting green urbanism is shadowed by socioeconomic globalization aims and non-compliance with regulations.

Energy policy implementation by international authorities is the product of multiple events [5]:

- Geopolitical tensions, which began in the 1970s with the first oil shock and led to an exponential increase in oil price;

- Increased demand for energy resources, due to industrial development and population growth has raised the question of the sustainability of fossil resources and the need to

*Corresponding author.

E-mail address: hainekamel@hotmail.fr 
find alternative renewable resources;

- Since the 1990 s, several groups have been developing scientific reports on climate change. Thus, the member states of the United Nations are mobilized against global warming through meetings at the Earth summits. This goal can be achieved by reducing greenhouse gas emissions, of which the energy sector is the main factor [6];

- As a result, many countries are working to replace non-renewable energy such as coal with a sustainable energy system defined by Alanne and Saari [7] as a system capable of generating sufficient, clean, sustainable and affordable energy.

The first aim is to analyse energy-efficient urban planning through the integration of solar electricity applications to four different studied areas: City Ibenbadis (Constantine, Algeria), Saint-Hugues (Quebec, Canada), Saint-Malo (France) and Ambolobozobe (Madagascar). The analysis compares the urban planning morphology development and $\mathrm{CO}_{2}$ reduction of European, North American, and African cities.

The second aim is to define a methodology and process for urban mid-term plan in three different continents: Africa, Europe, and North America, taking into consideration several factors which are: demographical growth, urban planning database, population needs, energy needs, and environmental planning information.

\section{Methodology AND Model Description}

The methodology used in this paper can be divided into two main parts (see Fig. 1): energy-efficient urban planning through solar energy applications in our studied areas Ibenbadis (Algeria), Saint-Hugues (Quebec, Canada), Saint-Malo (France) and Ambolobozobe (Madagascar) using an algorithm created by Amado and Poggi [9] for sustainable urban planning organized in seven steps:

1. Energy efficiency and sustainability goals for the studied urban areas were defined;

2. Analysis of data bases (urban and land use, population, environmental and climate);

3. Analysis of databases for solar energy and the potential of the studied areas;

4. GHG data for indicators, $\mathrm{CO}_{2}$ emissions for different studied areas were calculated;

5. Master plan designing for the studied areas including a model calculation of solar energy production;

6. Mid-term master plan conception and $\mathrm{CO}_{2}$ reduction calculation model;

7. Midterm new master plan is developed for the studied areas with a successful energy performance and environmental regulation integration.

Comparative analysis of solar potential is calculated for the four studied areas located in three continents using four factors as follows: global solar radiation and duration time integrated into radiation index; tariff structure and maximum values integrated into tariff index; $\mathrm{CO}_{2}$ emissions from electricity production; current PV solar efficiency and midterm evaluation.

The first step of solar integration on the studied areas is to consider economic, environmental and social criteria, as well as land-use patterns by setting an urban analysis that allows defining aspects of our studied area, such as annual population growth, building density, shading constraints, and typology of the areas. 


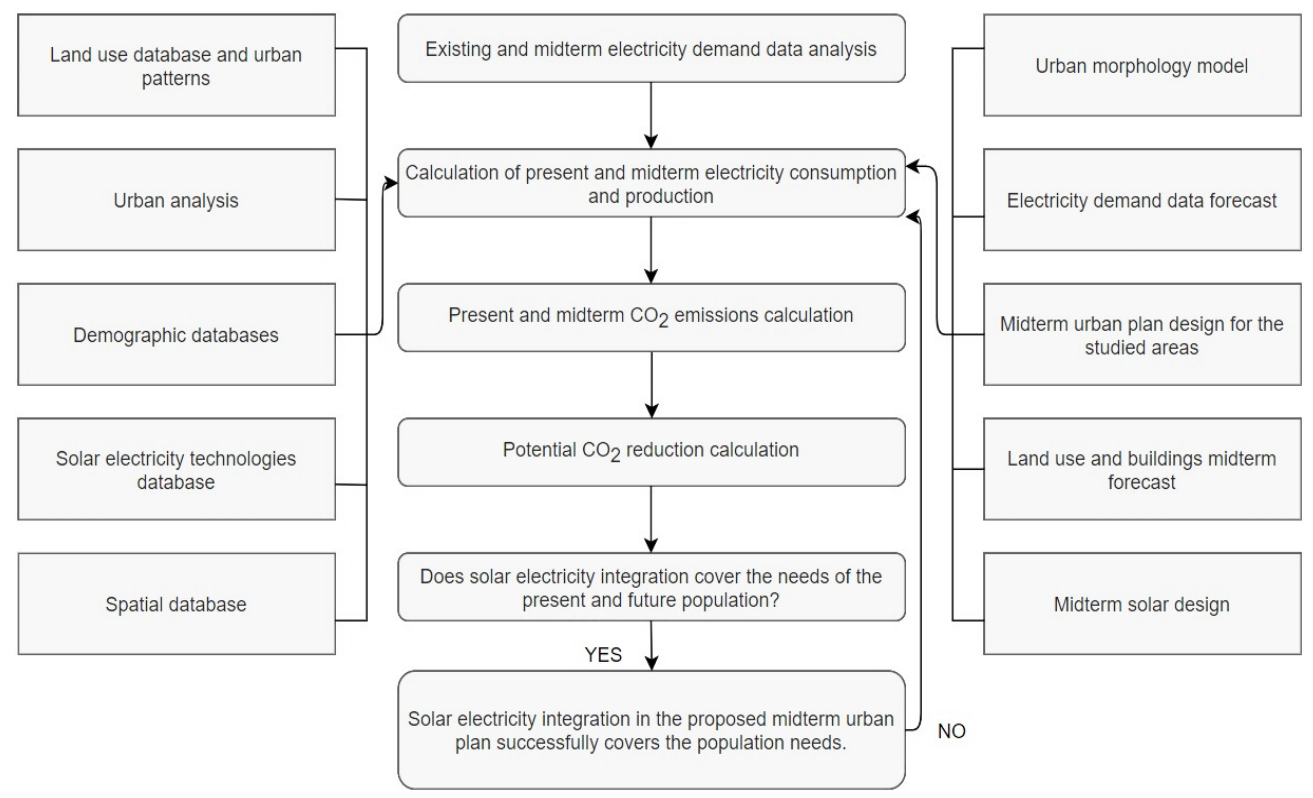

Fig. 1. Methodology for research study - energy-efficient urban planning through solar energy application.

Then, the energy analysis and solar estimation approach must include all the information and data about the solar and urban analyses for the existing and future urban plan to design a 3D model and solar simulation. Using ArcGIS and AutoCAD programmes the roof classification and facades surface for the existing situation are determined; this makes it possible to produce the solar simulation and build the 3D model. According to Miguel Amado Francesca Poggi (2012), the relationship between the maximum power and the efficiency of the PV module makes it possible to define the minimum surface area of usable roofs, which is fixed at approximately $7.6 \mathrm{~m}^{2}$ [9]. The following parameters and characteristics are respected in our study for reaching optimum efficiency by using a simplified parametric model on the solar simulation: roof areas and roof orientation, tilt angle and photovoltaic position.

The predicted annual energy yield for PV systems is calculated using the Eq. (1) [9]:

$$
\text { AnnualPV energy production }=P R \cdot M \mathrm{e} \cdot V_{\mathrm{st}} \cdot(A \cdot G \mathrm{r} \cdot 365) \text {, }
$$

where

$P R \quad$ Performance ratio which is assumed to 0.75 ( $P R$ is to consider the energy losses in the balance of system [8]);

$M_{\mathrm{e}} \quad$ PV module efficiency which is assumed to be 0.13 ;

$V_{\text {st }} \quad$ Solar radiation values at standard test conditions of irradiance assumed $1 \mathrm{kWh} / \mathrm{m}^{2}$;

$A \quad$ Incident on the available roof areas;

$G_{\mathrm{r}} \quad$ Annual global solar radiation [11]. 


\section{MODEL ANALYSIS}

\subsection{Urban Analysis}

\subsubsection{Ibenbadis}

Ibenbadis is located $40 \mathrm{~km}$ from the city Constantine in Algeria, and it has a surface area of 4.4 ha. The master plan of Constantine is the urban planning tool of the city [10], which defines land-use patterns by showing the actual zones of the studied area and nature of their activities; Table 1 summarizes the characteristics of the actual situation. The organization of the urban space of Ibenbadis is characterized by homogeneity of its fabric.

Ibenbadis surface area is divided into 95 land parcels located in a flat area with different shapes and a surface between $70 \mathrm{~m}^{2}$ to $800 \mathrm{~m}^{2}$. Ibenbadis is mainly a residential area composed of 7 buildings and 170 dwellings used by 1324 inhabitants and an annual population growth rate of $5 \%$.

\subsubsection{Saint-Hugues}

Saint-Hugues is a municipality in the regional county municipality of Maskoutains in Quebec (Canada), it is a residential area with a surface area of 35 ha for a total number of inhabitants in 2015 of 1362 . The urban and town planning tool of Canada allows us to define the municipality of Saint-Hugues urban form, which are homogeneous forms in the centre, surrounded by less dense sectors and in the south by institutional areas. The western and northern boundaries present an unfinished urbanization project applying suburban models by the shape of streets and land parcels. The general composition of the area and the characteristics of the land use are defined as a residential area; Table 1 illustrates the current situation of the municipality.

The urban analysis plan of the municipality illustrates the location of buildings, roads, and streets. The concentration of buildings is organized according to two logics: the first group of buildings stretches along the rural roads that serve the municipality, in a linear development; the second group of buildings focuses on nine orthogonal land parcels that form the residential heart of the municipality, which are mostly areas between $500 \mathrm{~m}^{2}$ to $1000 \mathrm{~m}^{2}$. The site is composed of 189 buildings located in a flat surface and has an annual population growth of $1.02 \%$.

\subsubsection{Saint-Malo}

Saint-Malo is located on the northern coast of the department Ille-et-Vilaine (France) with a surface area of 3658 ha and a population of 45719 inhabitants and an annual population growth rate of $0.82 \%$. The municipality is marked by a heterogeneous landscape: hilly with areas at sea level and others at about $50 \mathrm{~m}$ above sea level. With the use of both France urbanization tools, first the urban local plan PLU (plan local d'urbanisme) and Coherent Territorial Planning Schemes - SCoT (Schéma de cohérence territorial), we could define the nature of the municipality and the land use share for the existing situation, Table 1 illustrates the current situation of the studied area.

Saint-Malo is a purely residential area in the mixed form of dwellings and buildings occupying plots with a surface area between 400 and $850 \mathrm{~m}^{2}$, with 2164 building and 12987 private houses. The site has a slope to the north, low between $0.9 \%$ and $1.4 \%$ north of the sector and medium to south between $3.5 \%$ and $5.5 \%$. 


\subsubsection{Ambolobozobe}

Ambolobozobe is located $25 \mathrm{~km}$ east of Andrafiabe commune and $59 \mathrm{~km}$ from the city of Antsiranana with a surface area of 11 ha. Street networks shape the urban forms that structures urban spaces and delimits homogeneous urban areas. Conducting the urban analysis allows us to define the land use pattern; the following Table 1 illustrates the share of activities and building typology. It defines the study area to be a residential and flat area with nearly $0 \%$ slope area with more than $60 \%$ comprising of residential area, with 426 private residences for 3303 inhabitants and an annual population growth rate of $1.5 \%$.

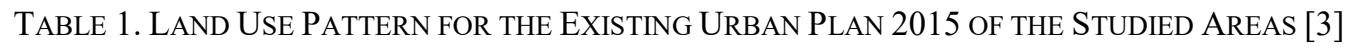

\begin{tabular}{lllll}
\hline $\begin{array}{l}\text { Distribution of land use } \\
\text { in 2015 urban plan }\end{array}$ & Ibenbadis & Saint-Hugues & Saint-Malo & Ambolobozobe \\
\hline Road and parking & $30 \%$ & $9 \%$ & $8 \%$ & $8 \%$ \\
Residential & $40 \%$ & $52 \%$ & $63 \%$ & $63 \%$ \\
Services & $4 \%$ & $1 \%$ & $0 \%$ & $0 \%$ \\
Industrial & $0 \%$ & $23 \%$ & $15 \%$ & $15 \%$ \\
Green & $11 \%$ & $12 \%$ & $6 \%$ & $6 \%$ \\
Sidewalk & $10 \%$ & $3 \%$ & $8 \%$ & $8 \%$ \\
Commercial & $5 \%$ & $9 \%$ & $8 \%$ & $8 \%$ \\
\hline
\end{tabular}

\subsection{Energy}

Applying the solar energy analysis to the studied areas allows defining the most suitable photovoltaic system and to forecast mid-term urban planning considering the annual consumption of different sectors and the electricity price.

Electricity consumption, price of electricity (EUR/MWh), and the use by sector (in kWh per person per annum) have been collected from the Algerian energy utility Sonalgaz Constantine, Canada Energy Regulator, Madagascar energy statistics and EDF France [7], and are summarized in Table 2.

TABLE 2. ENERgy ANALysis OF THE STUdied AREAS [7]

\begin{tabular}{|c|c|c|c|c|c|}
\hline \multirow{4}{*}{$\begin{array}{l}\text { Electricity } \\
\text { consumption } \\
\text { by sector }\end{array}$} & Studied Area & $\begin{array}{l}\text { Ibenbadis } \\
\text { (Algeria) }\end{array}$ & Saint-Hugues & Saint-Malo & $\begin{array}{l}\text { Ambolobo-zobe } \\
\text { (Madagas-car) }\end{array}$ \\
\hline & $\begin{array}{l}\text { Residential } \\
\text { (consumption } \\
\text { per capita) }\end{array}$ & $3700 \mathrm{kWh} /$ person/y & $9720 \mathrm{kWh} /$ person/year & $\begin{array}{l}7200 \\
\mathrm{kWh} / \text { person/year }\end{array}$ & $\begin{array}{l}1100 \\
\mathrm{kWh} / \text { person/year }\end{array}$ \\
\hline & $\begin{array}{l}\text { Mixed-use: } \\
\text { Residential, } \\
\text { Commercial }\end{array}$ & $180 \mathrm{kWh} / \mathrm{m}^{2} / \mathrm{y}$ & $7200 \mathrm{kWh} /$ person/year & $\begin{array}{l}14400 \\
\mathrm{kWh} / \text { person/year }\end{array}$ & $90 \mathrm{kWh} / \mathrm{m}^{2} / \mathrm{y}$ \\
\hline & $\begin{array}{l}\text { Industrial and } \\
\text { other } \\
\text { specialized } \\
\text { structures }\end{array}$ & $311 \mathrm{kWh} / \mathrm{m}^{2} / \mathrm{y}[4]$ & $17200 \mathrm{kWh} /$ person/year & $\begin{array}{l}14400 \\
\mathrm{kWh} / \text { person/year }\end{array}$ & $250 \mathrm{kWh} / \mathrm{m}^{2} / \mathrm{y}$ \\
\hline $\begin{array}{l}\text { Electricity } \\
\text { price }\end{array}$ & $\begin{array}{l}\text { High consume } \\
\text { hours }\end{array}$ & $38 \mathrm{EUR} / \mathrm{MWh}$ & $92 \mathrm{EUR} / \mathrm{MWh}$ & $156 \mathrm{EUR} / \mathrm{MWh}$ & $81 \mathrm{EUR} / \mathrm{MWh}$ \\
\hline
\end{tabular}


Table 3 summarizes solar energy data of the direct and diffused radiation; the energy data was collected from the German Aerospace Agency [11].

TABLE 3. Solar Radiation OF THE StUdied AREAs [10]

\begin{tabular}{llllll}
\hline Solar radiation & Units & Ibenbadis & Saint-Hugues & Saint-Malo & Ambolobozobe \\
\hline Global radiation & $\mathrm{MWh} / \mathrm{m}^{2}$ year & 1.9 & 1.5 & 1.3 & 2.5 \\
Radiation duration & $\mathrm{h} /$ year & 3000 & 1200 & 1600 & 2900 \\
\hline
\end{tabular}

\section{Solar potential estimation}

The application of the geographical information system software ArcGIS and AutoCAD tools allows us to define the typology of the facades and roofs as well as their orientation; it also allows determining the net available roof surface for PV [12]. As mentioned in the previous chapter, the minimum usable roof area for the selected PV system, determined by the relation between the photovoltaic module efficiency and the maximum power, is approximately $7.6 \mathrm{~m}^{2}$. Table 4 summarizes the parameters for calculation of PVs produced electricity.

For the studied area of Ibenbadis, results indicate that the roof's solar energy potential for the actual urban plan is $2861 \mathrm{MWh} / \mathrm{y}$ while electricity consumption is $3700 \mathrm{kWh} /$ person per year. The current urban plan covers the needs of $58 \%$ of the population with renewable energy. It can be concluded that poor orientation and configuration of the roofs to solar radiation does not allow the optimum exploitation of the solar energy in the urban areas.

For Saint-Hugues, the electricity production from solar integration on the roofs represents $31528 \mathrm{MWh} / \mathrm{y}$, which covers the energy needs of the existing population, and for the studied area, the Saint-Malo electricity production would be $3050824 \mathrm{MWh}$ and cover $92 \%$ of the population needs. For the studied area of Ambolobozobe, the electricity production in the existing urban plan is $17639 \mathrm{MWh}$, for the actual plan, the energy need is fully covering the needs of the population.

\subsection{Environmental Analysis}

Conducting an environmental analysis allows us to define the $\mathrm{CO}_{2}$ emissions due to residential electricity consumption for the studied areas using the equation below [12]; results and details about each studied area are presented in Table 5.

$$
\mathrm{CO}_{2} \text { emissions emitted from residential electricity consumption }=A \cdot F,
$$

where

$A \quad$ Electricity consumption, $\mathrm{kWh}$; and

$F \quad \mathrm{CO}_{2}$ emission coefficient in the power grid of the region, tonnes $/ \mathrm{kWh}$. 
TABLE 4. PVs Produced ENERGY ON EXISTING RoOF AREAS

\begin{tabular}{|c|c|c|c|c|c|c|c|c|c|c|c|c|c|c|c|c|}
\hline \multirow{2}{*}{$\begin{array}{l}\text { Buildings, } \\
\text { current use }\end{array}$} & \multicolumn{4}{|c|}{ Gross roofs area, $\mathbf{m}^{2}$} & \multicolumn{4}{|c|}{$\begin{array}{l}\text { Total available roof area for } \\
\text { PV installation, } \mathbf{m}^{2}\end{array}$} & \multicolumn{4}{|c|}{$\begin{array}{l}\text { Mean annual global radiation } \\
\text { on available roof area, } M W h / / y\end{array}$} & \multicolumn{4}{|c|}{$\begin{array}{c}\text { Predicted annual yield } \\
\text { for PV systems on available roof } \\
\text { area, MWh/y }\end{array}$} \\
\hline & $\mathrm{DZ}$ & $\mathrm{CA}$ & FR & MG & $\mathrm{DZ}$ & $\mathrm{CA}$ & FR & MG & $\mathrm{DZ}$ & $\mathrm{CA}$ & FR & MG & $\mathrm{DZ}$ & $\mathrm{CA}$ & FR & MG \\
\hline Residential & 17600 & 182000 & 23045400 & 75900 & 12320 & 127400 & 16131780 & 53129 & 23408 & 191100 & 20971314 & 132822 & 2282 & 18632 & 2044703 & 12950 \\
\hline $\begin{array}{l}\text { Industrial, } \\
\text { spec. }\end{array}$ & 0 & 3500 & 0 & 2200 & 0 & 2449 & 0 & 1540 & 0 & 3673 & 0 & 3850 & 0 & 358 & 0 & 375 \\
\hline $\begin{array}{l}\text { Service, } \\
\text { private space }\end{array}$ & 1760 & 80500 & 5487000 & 11000 & 1232 & 56349 & 3840899 & 7699 & 2341 & 84523 & 4993169 & 19247 & 228 & 8240 & 486833 & 1876 \\
\hline Commercial & 2200 & 10500 & 2926400 & 9900 & 1540 & 7349 & 2048479 & 6929 & 2926 & 11023 & 2663022 & 17322 & 285 & 1074 & 259644 & 1688 \\
\hline Unclass. & 500 & 31500 & 2926400 & 4400 & 350 & 22049 & 2048479 & 3079 & 665 & 33073 & 2663022 & 7697 & 64 & 3224 & 259644 & 750 \\
\hline Total & 22060 & 308000 & 34385200 & 103400 & 11000 & 215596 & 24069637 & 72376 & 29340 & 323392 & 31290527 & 180938 & 2861 & 31528 & 3050824 & 17639 \\
\hline
\end{tabular}

TABLE 5. EMISSIONS DUE TO RESIDENTIAL ELECTRICITY CONSUMPTION ON EXISTING URBAN PLAN

\begin{tabular}{lll}
\hline Studied area & $\begin{array}{l}\text { Emission factors for } \\
\text { consumed electricity }\end{array}$ & $\mathbf{2 0 1 5}$ \\
\hline Ibenbadis (Algeria) & $0.66 \mathrm{~kg} \mathrm{CO} / \mathrm{kWh}$ & $3233 \mathrm{tCO}_{2}$ \\
Saint-Huges (Canada) & $0.17 \mathrm{kgCO}_{2} / \mathrm{kWh}$ & $2286 \mathrm{tCO}_{2}$ \\
Saint-Malo (France) & $0.07 \mathrm{kgCO}_{2} / \mathrm{kWh}$ & $23042 \mathrm{tCO}_{2}$ \\
Ambolobozobe (Madagasacar) & $0.58 \mathrm{kgCO}_{2} / \mathrm{kWh}$ & $2107 \mathrm{tCO}_{2}$ \\
\hline
\end{tabular}




\section{Results}

By forecasting the growth of the population, taking into consideration the annual population growth rate for each studied area and urban planning strategy adopted by each country and energy analysis for the mid-term, we obtain the result of the new urban plan for the studied areas.

Estimation of the facility coefficient for the new urban area has been assumed $C_{\mathrm{f}}=0.80$ according to the available area per capita $A_{\mathrm{a}} / \mathrm{ca}=17.3$ and densities parameters.

It is assumed in this study that the reduction factor for the roof areas is $15 \%$. In this new urban model, the facades larger than $37 \mathrm{~m}^{2}$ have been considered; similar to roofs, the area of the facade must be affected by several reduction factors such as window, orientation, and geometry. For more accurate results, we have excluded the facades facing streets and private areas.

According to the two buildings typologies introduced by urban renewal, we have considered a reduction coefficient to be $F_{\mathrm{g}}=0.5$ (two-storey building) and $F_{\mathrm{g}}=0.67$ (three-storey building) [11].

\subsection{Urban Planning Results}

\subsubsection{Ibenbadis}

The new urban plans for the city of Ibenbadis are divided into 60 land parcels with different shapes and a surface between $70 \mathrm{~m}^{2}$ to $800 \mathrm{~m}^{2}$ [14], containing 40 extra dwellings with a flat roof typology and a roof surface greater than $42 \mathrm{~m}^{2}$; the 40 new dwellings are in an area with good solar radiation. The designed midterm urban model is characterized by a right roof orientation in the direction of solar radiation and respects the rule of $45^{\circ} \mathrm{C}$ between windows and walls, which results in a reduction of shading and good solar access.

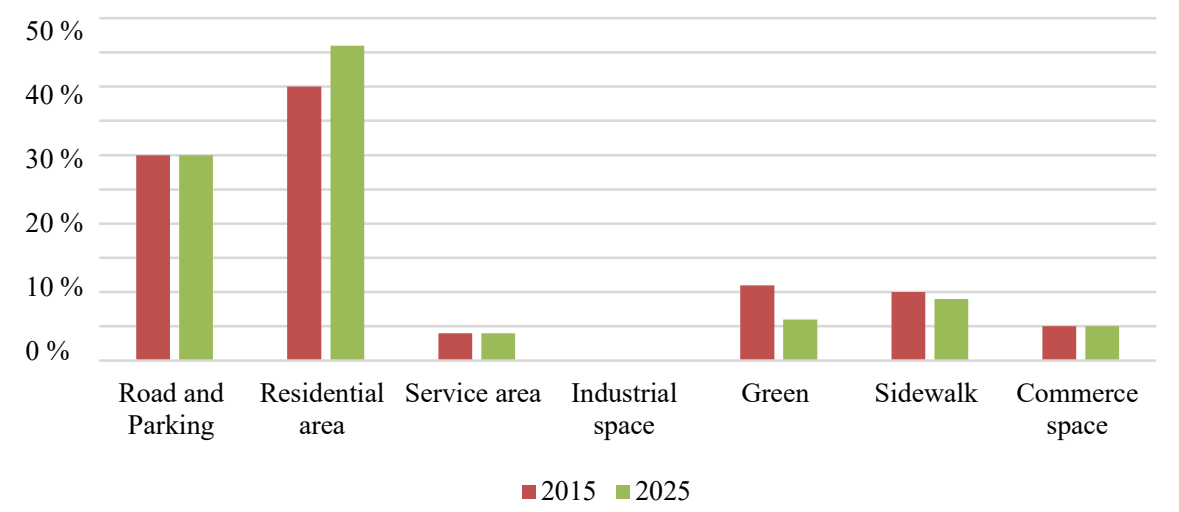

Fig. 2. Mid-term urban plan and land share of the city of Ibenbadis [9].

\subsubsection{Saint-Hugues}

The average annual population growth rate in Canada is $1.2 \%$, after our urban analysis we could define the exact annual population growth rate for our studied area which is $1.02 \%$, 
this allowed us to forecast the growth of the population for midterm 2025 to be 1660 inhabitants.

On the new urban model, we have kept the same organization of the municipality to preserve its historical heritage by keeping the same number of parcels and expanding the area on the non-constructed area in the municipality by planning eight new buildings. The designed midterm urban model respects the rule of $45^{\circ} \mathrm{C}$ between windows and walls, which results in a reduction of shading and good solar access [15], [16] (see Fig. 3).

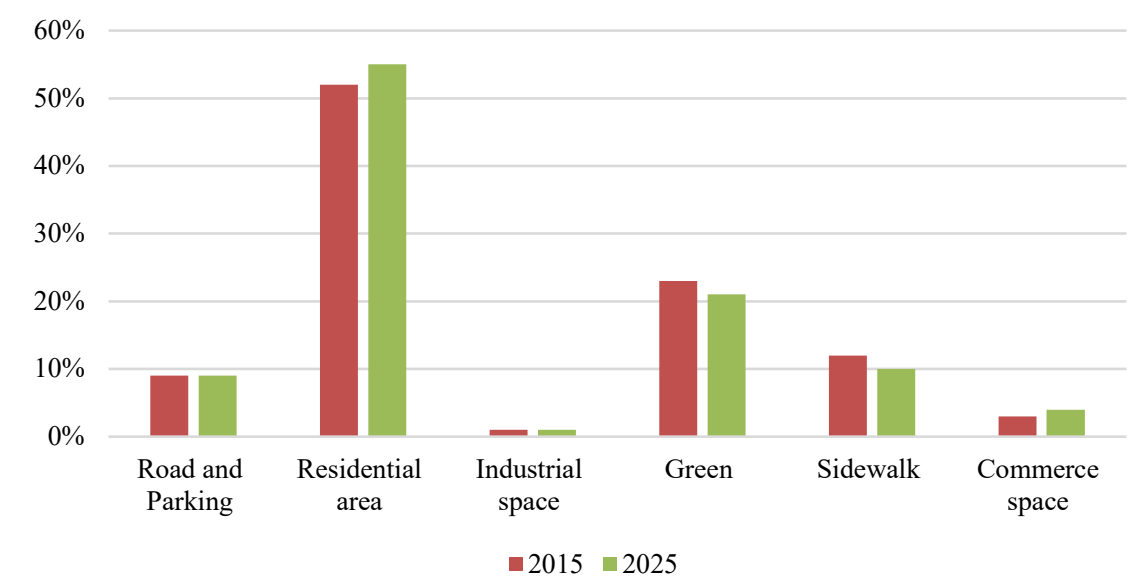

Fig. 3. Land use share for new urban mad mid-term of Saint-Hugues.

\subsubsection{Saint-Malo}

From the demographical analysis, we could determine the average annual population growth rate in the municipality of Saint-Malo as $0.83 \%$, taking into consideration the current population of 45719 allowed us to forecast the population of the municipality for the midterm be 49653 inhabitants.

The development of the municipality in the mid-term will allow for the establishment of individual housing, collective, and semi-collective (Fig. 4). The future development project will be spread over approximately 18 ha in urban development north-east of Saint-Malo to cover the population needs with 51 new buildings and 300 new private houses. The midterm model respects rule of $45^{\circ} \mathrm{C}$ between walls and windows, which allows perfect solar access and reduces the shading for the existing buildings.

\subsubsection{Ambolobozobe}

The development of the municipality in the mid-term will allow the establishment of housing in individual types for the new population and this to keep the same characteristics of the area as well to fulfil the needs of the population. In the midterm, the population will reach 3800 inhabitants, as the demographical growth ratio in the municipality is considered to be $1.5 \%$ per year (Fig. 5). 


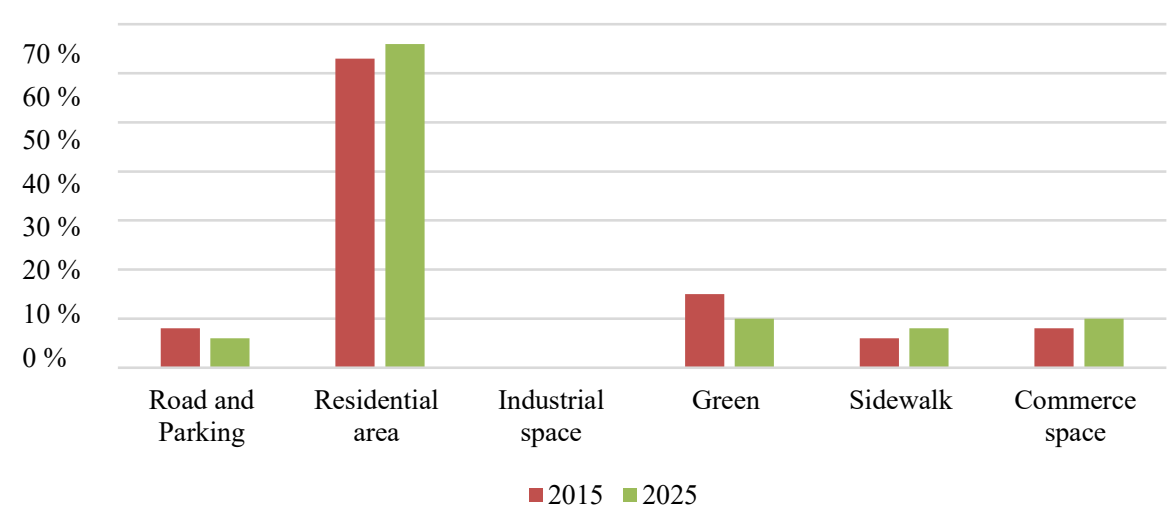

Fig. 4. Land use share for new urban mad mid-term of Saint-Malo.

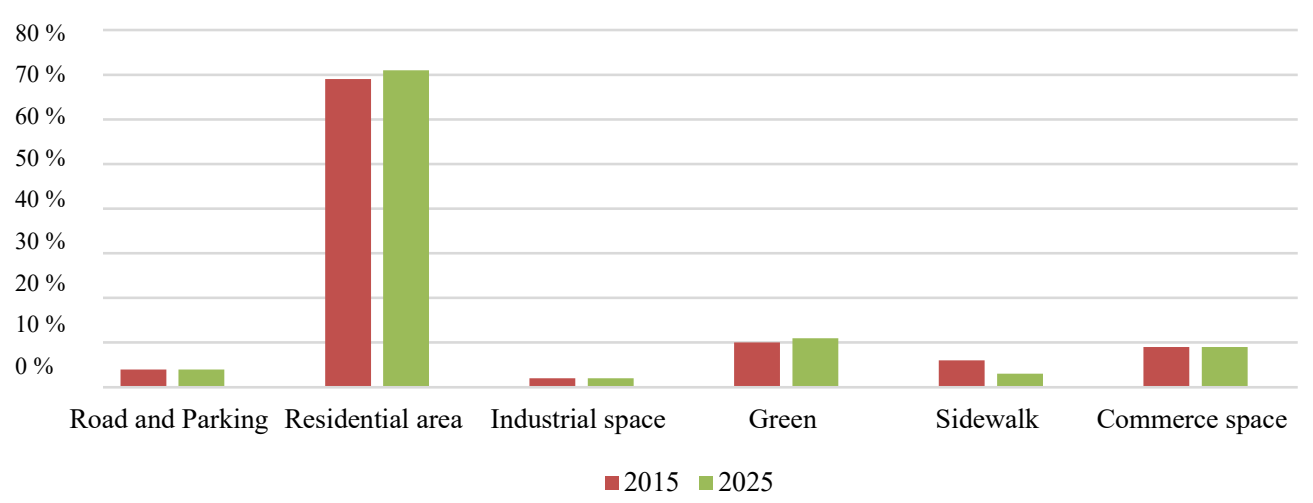

Fig. 5. Land use share for new urban mad mid-term of Ambolobozobe.

\subsection{Energy Analysis Results}

The new urban plan uses a similar approach described in the methodology to calculate the solar potential on building roofs and facades; Table 6 summarizes PV energy production estimation on roofs and facades considering the designed midterm urban plan for the studied areas.

The new urban model dated for the midterm of the studied area Ibenbadis (Algeria), that has PVs integrated on the facades and roofs of dwellings and buildings generates $6922 \mathrm{MWh} /$ year. The electricity generated covers the needs of 4000 inhabitants, while the forecasted number of inhabitants is only 1700. The annual yield for PV systems on roofs and facades for the new urban plan design for the case of Saint-Hugues generates $59592 \mathrm{MWh} /$ year that can cover electricity needs of a population of 6143 inhabitants whilst the planned number of populations in the midterm will be only 1660 inhabitants. 
TABLE 6. Results of PV ENERGy PRODUCTION ESTIMATION ON ROOFS AND FACADES CONSIDERING NEW URBAN Plans FOR THE STUdIED AREAS

\begin{tabular}{lllll}
\hline $\begin{array}{l}\text { Predicted annual yield for PV } \\
\text { systems on roofs and façade, } \\
\text { MWh/y }\end{array}$ & Ibenbadis & Saint-Hugues & Saint- Malo & Ambolobozobe \\
\hline $\begin{array}{l}\text { Residential } \\
\begin{array}{l}\text { Industrial and other specialized } \\
\text { structures }\end{array}\end{array}$ & 3300 & 41698 & 3542521 & 31898 \\
Service & 322 & 758 & 0 & 899 \\
Commercial & 372 & 14103 & 475481 & 43779 \\
Total & 6922 & 5932 & 396731 & 4941 \\
\hline
\end{tabular}

For the case of Saint-Malo, the results show that the generated energy in the midterm will be $4414734 \mathrm{MWh} /$ year, which by far covers the total amount of the population needs. The new urban model of the municipality of Ambolobozobe provides a result of $81517 \mathrm{MWh} /$ year, knowing that the population of the area is only 3800 inhabitants we can conclude that the population needs are fully covered as the new urban plan have the capacity of covering the electricity needs of 74106 inhabitants.

\section{ECONOMiC ANAlysis OF RESUlts}

Comparison of solar electricity integration in the urban plan of the four studied areas (three continents) having various characteristics for energy production, global solar radiation, solar radiation duration and price of $\mathrm{PVs}$ is based on the mathematical conversion of independent variables which affects the decision of implementation over the years in the short term and midterm. As shown in the results, despite the enormous solar radiation potential and duration in African countries, we can see that in the case of Algeria the result in the mid-term 2025 is almost similar to Canada, this is due to the solar electricity price which is higher in developing countries due to the high costs of solar technologies in the emerging countries. The residential PV system's total installed cost is continuously decreasing. Energy from PV solar has seen the most significant price drop in the last decade, which makes it nowadays an essential factor for solar energy integration in urban planning (See Fig. 6).

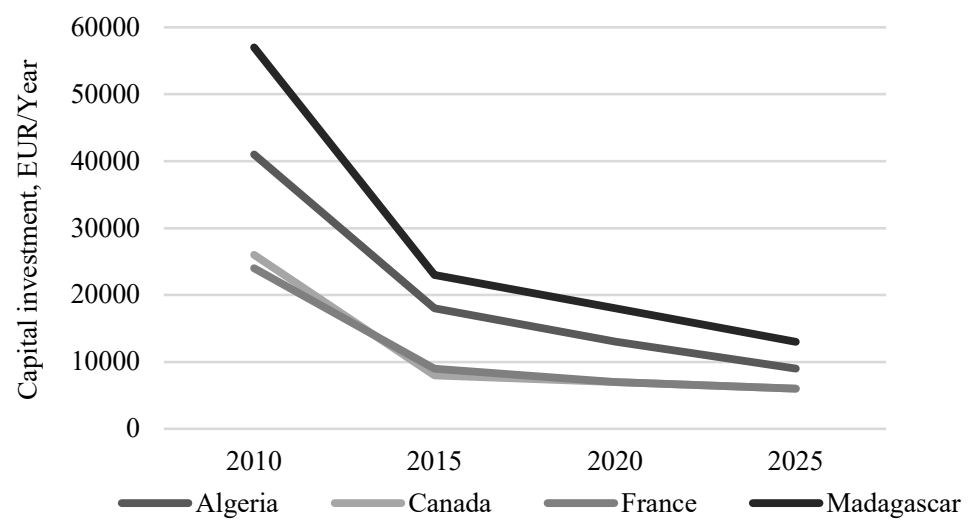

Fig. 6. Capital investment for $1000 \mathrm{~m}^{2}$ installed PV in terms of solar electricity price evolution per country. 


\section{CONCLUSION}

The method conducted on our research allowed us to have an overview of solar potential integration in urban areas and solar energy for electricity generation. It as well highlights the importance of urban strategies such as the orientation of the buildings, roofs, and facade typologies: Consequently, solar PVs for the current situation cover $58 \%$ of the electricity needs of Ibenbadis population and $92 \%$ for Saint-Malo. For the case of Saint-Hugues and Ambolobozobe, the existing urban morphology, roof typology, and orientation allows a $100 \%$ coverage of electricity needs in the current urban plan.

Concerning the new urban plan for the midterm, taking into consideration the solar energy implementation in the facades and roofs for the existing and new dwellings and buildings, the consumption of electricity of the population in the two case studies is covered.

From our study it can be concluded that the sunniest locations are not necessarily the most favourable to the implementation of solar energy and all the constraints and criteria must be accounted for before implementation. The overall methodology of this study can be used for urban development in any other cities worldwide. However, each step demands local expertise and respect of local urban planning tools.

Urban planning has to include the analysis of economic calculations of solar power generations and modelling of policy tools (grants, subsidies, and taxes) for the support of renewable electricity production. Based on the comparative analysis, it can be declared that the tariff index has a dominating effect on the economic sustainability of solar systems integrated into urban areas.

\section{REFERENCES}

[1] Aschwanden G. D. P. A., et al. Empiric design evaluation in urban planning. Automation in Construction 2011:20(3):299-310. https://doi.org/10.1016/j.autcon.2010.10.007

[2] Oliveira V., Pinho P. Evaluation in Urban Planning: Advances and Prospects. Journal of Planning Literature 2010:24(4):343-361. https://doi.org/10.1177/0885412210364589

[3] Amado M., Poggi F., Amado A. R. Energy efficient city: A model for urban planning. Sustainable Cities and Society 2016:26:476-485. https://doi.org/10.1016/j.scs.2016.04.011

[4] Poggi F., Firmino A., Amado M. SMART RURAL: A model for planning net-zero energy balance at municipal level. Energy Procedia 2017:122:56-61. https://doi.org/10.1016/j.egypro.2017.07.287

[5] Godinot S. Territorial energy climate plans: ways of appropriation of factor 4 by local authorities and actors? Sustainable development and territories. Economics, Geography, Politics, Law, Sociology 2011:2(1).

[6] Paillard C. Défis énergétiques et enjeux stratégiques au XXIe siècle. (Energy Challenges and Strategic Challenges in the 21 st Century). Securite Globale, 2011. (In French).

[7] Alanne K., Saari A. Distributed energy generation and sustainable development. Renewable and Sustainable Energy Reviews 2006:10(6):539-558. https://doi.org/10.1016/j.rser.2004.11.004

[8] Marillier F. Crise énergétique : il n'est pas trop tard pour s'en sortir! (Energy crisis: it's not too late to get out!) Nouvelles Foundations, 2007. (In French).

[9] Amado M., Poggi F. Towards solar urban planning: a new step for better energy performance. Energy Procedia 2012:30:1261-1273. https://doi.org/10.1016/j.egypro.2012.11.139

[10] Plan d'Occupation des Sols Constantine 2015 Outil d'amenagement et d'urbansime pour la ville de Constantine Algérie. (Constantine Soil Occupancy Plan 2015 Urban and urban planning tool for the city of Constantine Algeria) (in French)

[11] German Aerospace Center. Concentrating Solar Power for the Mediterranean Region. Final Report. Stuttgart: DLR, 2012.

[12] Algerian Map, BenBadis area. ArcGis Software 2010

[13] Chen H., Jia B., Lau S. S. Y. Sustainable urban form for Chinese compact cities: challenges of a rapid urbanized economy. Habitat International 2008:32(1):28e40. https://doi.org/10.1016/j.habitatint.2007.06.005

[14] Ranalli J., et al. Toward comprehensive solar energy mapping systems for urban electricity system planning and development. The Electricity Journal 2018:31(1):8-15. https://doi.org/10.1016/j.tej.2018.01.002 
$2020 / 24$

[15] Geros V., et al. A distant-learning training module on the environmental design of urban buildings. Renewable Energy 2006:31(15):2447-2459. https://doi.org/10.1016/j.renene.2005.11.011.

[16] Bojić M., et al. Toward a positive-net-energy residential building in Serbian conditions. Applied Energy 2011:88(7):2407-2419. https://doi.org/10.1016/j.apenergy.2011.01.011 